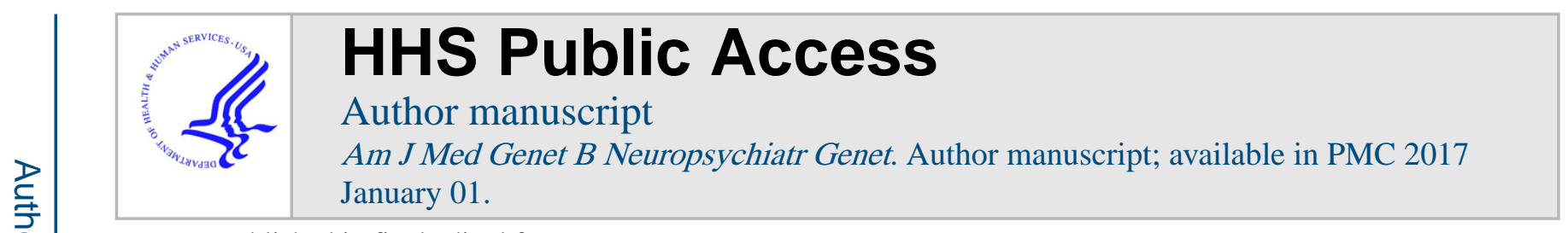

Published in final edited form as:

Am J Med Genet B Neuropsychiatr Genet. 2017 January ; 174(1): 27-35. doi:10.1002/ajmg.b.32413.

\title{
Genetics of Psychosis of Alzheimer Disease
}

Chintan Shah ${ }^{1}$, Mary Ann A. DeMichele-Sweet ${ }^{1}$, and Robert A. Sweet ${ }^{2,3,{ }^{*}}$

${ }^{1}$ Department of Psychiatry, University of Pittsburgh, Pittsburgh, Pennsylvania

${ }^{2}$ Department of Psychiatry and Neurology, University of Pittsburgh, Pittsburgh, Pennsylvania

${ }^{3}$ VISN 4 Mental Health Illness Research, Education and Clinical Center (MIRECC), VA Pittsburgh Healthcare System, Pittsburgh, Pennsylvania

\begin{abstract}
Psychotic symptoms, comprised of delusions and hallucinations, occur in about half of individuals with Alzheimer disease (AD with psychosis, $\mathrm{AD}+\mathrm{P}$ ). These individuals have greater agitation, aggression, depression, functional impairment, and mortality than individuals without psychosis (AD-P). Although the exact etiopathogenesis of $\mathrm{AD}+\mathrm{P}$ is unclear, the rapidly developing field of genomics continues to expand our understanding of this disease. Several independent studies have demonstrated familial aggregation and heritability of $\mathrm{AD}+\mathrm{P}$. Linkage studies have been suggestive of loci on several chromosomes associated with $\mathrm{AD}+\mathrm{P}$. Association studies examining apolipoprotein $\mathrm{E}$ gene, the best established genetic risk factor for late-onset $\mathrm{AD}$, did not find any significant association of this gene with $\mathrm{AD}+\mathrm{P}$. Other candidate gene studies focusing on monoamine neurotransmitter systems have yielded equivocal results. A genome-wide association study and studies examining copy number variations recently have detected suggestive associations, but have been underpowered. Approaches to increase sizes of $\mathrm{AD}+\mathrm{P}$ samples for genome wide association studies are discussed.
\end{abstract}

\section{Keywords}

Alzheimer disease; psychosis; genome-wide association; heritability

\section{INTRODUCTION}

Alzheimer disease (AD) is a neurodegenerative illness that currently affects 5.3 million Americans with numbers projected to grow to over 10 million by mid-century. The genetics of $\mathrm{AD}$ is subdivided into early-onset $\mathrm{AD}$ (EOAD) and late-onset $\mathrm{AD}$ (LOAD). EOAD typically has an onset prior to age 60 years and accounts for less than $5 \%$ of all cases [Campion et al., 1999; Bertram and Tanzi, 2005]. It usually follows an autosomal dominant inheritance pattern where mutations in a single gene can cause the disease. Mutations in presenilin 1 (PSEN1), presenilin 2 (PSEN2), and amyloid precursor protein (APP) have been reported in development of EOAD [Goate et al., 1991; Levy-Lahad et al., 1995; Sherrington et al., 1995]. Over the past decade, duplication of $A P P$ has also been described as a cause of

*Correspondence to: Robert A. Sweet, M.D., Department of Psychiatry and Neurology, University of Pittsburgh, Pittsburgh, PA 15213. sweetra@upmc.edu. 
EOAD [Rovelet-Lecrux et al., 2006]. LOAD has an onset after age 60 years and is the more prevalent form of $\mathrm{AD}$. The genetics of LOAD is more complex involving multiple genes with only modest familial aggregation. Apolipoprotein $\mathrm{E}(A P O E)$ is the most wellestablished gene associated with LOAD where individuals with e4 allele ( $A P O E$ e4) have a substantially higher risk of developing AD [Corder et al., 1993; Strittmatter et al., 1993]. Genome-wide associations studies (GWAS) have identified over 20 additional genetic loci for LOAD [Chouraki and Seshadri, 2014].

About $50 \%$ of individuals with AD will develop psychotic symptoms, (AD with psychosis, AD+P) [Murray et al., 2014]. These symptoms include hallucinations and delusions. Common delusions include those of persecution, infidelity, abandonment or deceased relatives being alive [Tariot et al., 1995]. Delusions must be distinguished from simple forgetfulness, often by their persistence or recurrence over time. Even though there is no fixed definition of persistence, the criteria used have ranged from more than two or three episodes in a week [Devanand et al., 1992; Sweet et al., 1998] to repeated episodes present for at least a month [Burns et al., 1990; Jeste and Finkel, 2000]. Hallucinations in AD can occur in any sensory modality, but visual and auditory hallucinations are most typical [Tariot et al., 1995]. One must be careful to distinguish visual hallucinations from illusions, or from normal hypnogogic and hypnopompic phenomena, and exclude any possible delirium that may be causing transient perceptual disturbances or delusional ideas [Jeste and Finkel, 2000]. Because some patients with AD may have infrequent distortions of thought or perception which may represent a true psychotic syndrome, or a phenocopy due to some of the above confounding circumstances, some investigators have classified such cases as AD + intermediate psychosis for association studies (e.g., [Zheng et al., 2014]). Another important consideration is the classification of individuals with $\mathrm{AD}$ as not psychotic for association testing. Psychotic symptoms typically emerge between the early and moderate stages of cognitive impairment in AD [Sweet et al., 2010]. Thus, to enhance the power of association testing, individuals should have reached at least this stage of impairment before being classified as $\mathrm{AD}$ without psychosis (AD without psychosis, AD-P).

The occurrence of psychotic symptoms in $\mathrm{AD}+\mathrm{P}$ identifies a subgroup of $\mathrm{AD}$ patients with a more severe phenotype. This includes greater cognitive impairment and more rapid cognitive decline when compared to AD-P patients [Ropacki and Jeste, 2005]. Moreover, AD+P is associated with higher rates of co-occurring agitation [Gilley et al., 1991], aggression [Gilley et al., 1997; Sweet et al., 2001], depression [Lyketsos et al., 2001; Sweet et al., 2010], caregiver burden [Kaufer et al., 1998], functional impairment [Scarmeas et al., 2005], and mortality [Wilson et al., 2006] than AD-P. Pharmacological interventions with typical and atypical antipsychotic medications have limited effectiveness and come with sizable risks [Schneider et al., 2006; Huybrechts et al., 2012]. These medications are FDA approved for schizophrenia and their use in treatment of psychosis of AD is off-label.

Given the disease burden of $\mathrm{AD}+\mathrm{P}$ and lack of efficacious treatments, it is imperative to pursue avenues that may lead us to the etiopathogenesis of this debilitating phenotype of AD. There have been numerous studies over the past several years looking at clinical correlates, brain imaging, and neuropathology related to $\mathrm{AD}+\mathrm{P}$. This review aims to summarize our current knowledge about the genetic basis of psychosis in $\mathrm{AD}$. We provide a 
review of studies examining the heritability and familial aggregation, linkage, candidate gene associations, genome wide association, and copy number variation studies, followed by a summary providing a critique of the existing findings.

\section{Heritability and Familial Aggregation}

Heritability is the extent to which individual genetic differences contribute to individual phenotypic differences. Familial aggregation refers to the occurrence of a given trait in two or more members of a family that cannot be readily accounted for by chance.

The first published study to look at familial aggregation of AD+P by Tunstall et al. [2000] found evidence for familiality of psychosis in AD to be equivocal. Sweet et al. [2002] found compelling evidence that $\mathrm{AD}+\mathrm{P}$ is familial. In a cohort of 371 subjects with $\mathrm{AD}$ and 461 siblings also diagnosed with $\mathrm{AD}$, collected as part of the National institute of mental health (NIMH) AD Genetics Initiative, it was found that $\mathrm{AD}+\mathrm{P}$ demonstrated familial aggregation. The odds ratio for $\mathrm{AD}+\mathrm{P}$ siblings of $\mathrm{AD}+\mathrm{P}$ probands was 2.4 (1.46-4.0). When the definition of psychosis was narrowed (requiring multiple psychotic symptoms to be present over time) the odds ratio (OR) of psychosis rose to 3.2 in siblings. Since then, the familiality of AD-related psychosis has been shown in two other studies of independent family cohorts [Hollingworth et al., 2007; Sweet et al., 2010].

Hollingworth et al. [2007] replicated and extended the 2002 study by Sweet et al. studying a subset of the NIMH AD Genetics Initiative families and a new set of families from the United Kingdom (UK). In total there were data from 374 families in which at least two members met criteria for AD and had complete data regarding psychotic symptoms. They found a significant association between proband psychosis status and the occurrence of AD $+\mathrm{P}$ in siblings in the UK $(\mathrm{OR}=4.17, P=0.002)$ and $\mathrm{US}(\mathrm{OR}=3.2, P<0.001)$ samples [Hollingworth et al., 2007].

In a later study by Sweet et al. [2010], they were able to verify previous familial aggregation studies when they looked at families with multiple members with LOAD. They identified 143 families in which at least two people were diagnosed with a dementia and characterized for the presence or absence of psychosis. There was a highly significant association of psychotic symptoms in the pro-band with the presence of psychosis in the family member ( $\chi^{2}=15.8, \mathrm{df}=4, P=0.003$ ). Once again, the association was strongest in comparing individuals with multiple/recurrent symptoms to those with no symptoms [OR (95\%CI) 3.80 $\left.(1.54-9.40) ; \chi^{2}=9.0, \mathrm{df}=1, P=0.003\right]$.

Evidence of familial aggregation of psychosis in $\mathrm{AD}$ suggests that this phenotype is under genetic control. Work done by Bacanu et al. [2005] first estimated heritability of psychosis in $\mathrm{AD}$ to be $61 \%$ in the NIMH AD Genetics Initiative families. More recently, Barral et al. [2015] examined an independent group of 607 families from the National institute of aging (NIA)-LOAD cohort and also found heritability of LOAD+P to be $61 \%$.

\section{Linkage Studies}

Having established heritability of $\mathrm{AD}+\mathrm{P}$, some questions that need exploration are: what loci may be linked to AD-related psychosis and what are the implicated genes? To answer such 
queries, in the first published linkage study, Bacanu et al. [2002] evaluated 65 families where two or more members had AD+P. They found evidence of linkage on chr 2p, 6 and 21. However, a later study [Hollingworth et al., 2007], showed that linkages on chr 6q16.3 and 21q22.13 appeared to be due to inclusion of APOE genotype as a covariate. The same group found a significant linkage on chr 7q21.11 (LOD $=2.84$ ) and 15q25 region (LOD $=3.16$ ) [Hollingworth et al., 2007].

Neuregulin-1 (NRG1), a gene on chromosome 8, has been linked with psychosis in schizophrenia [Stefansson et al., 2002; Harrison and Law, 2006]. Go et al. [2005] examined 437 families and found linkage for NRG1 with AD+P. They then analyzed four SNPs within NRG1 for linkage and association with $\mathrm{AD}+\mathrm{P}$ in a predominantly Anglo-European sample. Three of these SNPs were associated with risk for schizophrenia (SNP8NRG221533, SNP8NRG243177, SNP8NRG2419) $\left[\chi^{2}=0.333,0.286,0.818\right.$ and $P=0.564,0.593,0.366$, respectively] and the fourth was an exonic SNP (rs3924999). However, rs3924999 was the only one to show significant association with $\mathrm{AD}+\mathrm{P}$ in single SNP analyses $(P=0.008)$. rs3924999 results in a missense mutation that changes arginine to glutamine, although the impact of this change is not known.

Avramopoulos et al. [2005] found a region on chromosome 14 is linked to the absence of hallucinations in $\mathrm{AD}+\mathrm{P}$. They examined 148 families with at least two siblings with age at onset of 50 years. They identified linkage to a locus on chr 14q24.3 (LOD =3.91) $4.3 \mathrm{Mb}$ from PSEN1 locus related to the absence of hallucinations. Sequencing of PSEN1 in the families with greatest linkage did not detect any coding or splice site variations and they concluded that presence of PSEN1 in the region might be coincidental. In addition, they found some suggestive linkage to the presence of delusions on chromosome $2 p$ (LOD $=1.98$ ) thereby supporting the findings of Bacanu et al. [2002].

Barral et al. [2015] evaluated 263 families from the NIA-LOAD cohort. These families, in which multiple family members had $\mathrm{AD}$, were separated into those in which at least one family member had $\mathrm{AD}$ and psychosis (LOAD+P, $\mathrm{n}=215$ ) and those in which no family member had psychosis (LOAD-P, $\mathrm{n}=48$ ). They carried out linkage analysis to the AD phenotype within each set. They found significant evidence for linkages on chromosome $19 \mathrm{q} 13.12$ in the LOAD+P families and identified SNP rs2945988 to have a strong suggestive association with psychosis $\left(P=8.7 \times 10^{-7}\right)$. Using additional Caribbean hispanic and nonhispanic Caucasian cohorts they conducted a meta-analysis of 246 SNPs in the 19q13.12 region. The strongest signal in all Caribbean hispanic datasets was found for SNP rs $10410711\left(P_{\text {meta }}=5 \times 10^{-5}\right)$, an intronic variant in ZNF566 gene (zinc-finger binding proteins are involved in transcription and, of interest, variants in a zinc-finger protein gene, $Z N F 804 A$ has been shown to increase susceptibility to psychosis, schizophrenia, and bipolar disorder [Steinberg et al., 2011]. When non-hispanic Caucasian cohorts were included, a 19q13.12 variant, rs 10421862, located $24 \mathrm{~kb}$ upstream of rs10410711 appeared strongly associated with LOAD+P $\left(P_{\text {meta }}=1.0 \times 10^{-5}\right)$. Interestingly, the earlier linkage study done by Hollingworth et al. [2007] also reported suggestive linkage ( $\mathrm{LOD}=1.86$ ) to chromosome 19 , about $5 \mathrm{Mb}$ upstream of the 19q13.12 region Barral et al. reported. Furthermore, genomic variation in 19q13.12 has been associated as a risk factor for other psychiatric disorders such as schizophrenia [Xu et al., 2008]. In a large schizophrenia Genome-wide 
association study a SNP was identified just $13 \mathrm{Mb}$ upstream of 19q13.12 region identified in the study by Barral et al. [2015] [Schizophrenia Working Group of the Psychiatric Genomics Consortium, 2014].

\section{Genetic Association Studies}

One way to determine in what way genetic factors might lead to psychosis in Alzheimer's disease is via studying specific genetic variations in $\mathrm{AD}+\mathrm{P}$ samples and comparing them to AD-P samples in association studies. These studies initially focused on variants in APOE and in candidate genes in the monoamine neurotransmitter systems.

APOE- $-A P O E$ is the best established genetic risk factor for LOAD. Therefore, many researchers have evaluated whether $A P O E$ e 4 increases risk of $\mathrm{AD}+\mathrm{P}$.

DeMichele-Sweet and Sweet [2010] reviewed 22 studies examining the association of the $A P O E$ e 4 allele with $\mathrm{AD}+\mathrm{P}$. The reports in this review, and one additional more recent study [Christie et al., 2012] had a conflicting pattern of results in which $A P O E$ e 4 genotype increased, decreased, or had no effect on psychosis risk. These conflicting findings may have resulted from the considerable variability in the subject populations, sample sizes (most of which were small, median sample size $=173$ ), definitions of $\mathrm{AD}+\mathrm{P}$, and analytic approaches. Hence, DeMichele-Sweet et al. [2011a] examined the association of AD+P with APOE in the Uniform data set from the National Alzheimer's coordinating center, comprising 2,317 predominantly (84.5\%) Anglo-European sample of individuals with AD of which 802 (34.6\%) had psychosis. They found no association of the APOE e4 alleles with AD+P (OR $=0.999, P=0.996)$.

Alternatively, conflicting findings regarding the association of $A P O E$ with $\mathrm{AD}+\mathrm{P}$ may have resulted if other genetic variation in partial linkage disequilibrium with the two SNP $A P O E$ e4 locus is causally related to $\mathrm{AD}+\mathrm{P}$. Recent investigations sequencing the $A P O E$ region on chromosome 19 identified a variable length poly-T repeat sequence in intron six of TOMM4O [Roses et al., 2010]. Individuals with APOE e3/e4 genotype and long poly-T repeats (defined as >27) had a much lower age of onset of LOAD than individuals with $A P O E$ e3/e4 genotype and short repeats [Roses et al., 2010]. Therefore, Chu et al. [2011] evaluated the impact of $A P O E$ genotype and TOMM 40 poly-T repeats on AD+P risk. They developed a novel statistical method for allele length calls for the poly-T polymorphism and found it had a trimodal distribution, which differed significantly by $A P O E$ e4genotype ( $\chi^{2}$ $=659, \mathrm{df}=10, P<0.001)$. Neither $A P O E$ e4genotype, TOMM4O repeat length, nor their joint effect associated with AD+P. Finally, in the GWAS study by Hollingworth et al. [2012], described below, including 1,299 cases with $\mathrm{AD}+\mathrm{P}$ and 735 with AD-P, no APOE/ TOMM4OSNPs were significant in the comparison of AD+P versus AD-P (all $P>0.2$ ). However, this latter negative finding may be limited as it should be noted that $A P O E$ rs 7412 and rs429358 are not genotyped on the arrays and that their linkage disequlibrium with the proxy markers is low.

Other genes-Numerous genetic association studies have focused on polymorphisms in serotonin and dopamine receptors and the catechol-O-methyltransferase (COMT) enzyme. The evidence from such studies to date is inconclusive (reviewed extensively in DeMichele- 
Sweet and Sweet, 2010). Results of these as well as polymorphisms in the D-Amino acid oxidase activator $(D A O A)$, amyloid precursor protein $(A P P)$, sortilin-related receptor (SORL1), $\beta$-site amyloid precursor protein cleaving enzyme (BACE1), and microtubuleassociated protein tau (MAPT) are summarized in Table I.

\section{Genome-Wide Association Studies}

GWAS, like genetic association studies, compare the frequency of alleles of a given variant in case and control populations. The difference is the number and selection of tested variants, which instead of being chosen based on a priori hypothesis of a few candidate genes and variants, covers the entire genome. By covering the whole genome one can detect in an unbiased fashion variants that may contribute to a disease. This makes GWAS a favorable method for the discovery of common genes associated with complex diseases, such as LOAD. A limitation of GWAS is that large sample sizes are required, in part due to the loss of statistical power from the conduct of multiple tests [Chouraki and Seshadri, 2014].

The first genome-wide association study of AD+P was done by Hollingworth et al. [2012]. This meta-analysis combined three AD GWAS datasets: GERAD1 [Harold et al., 2009], the NIA-LOAD Family study [Sweet et al., 2010; Wijsman et al., 2011] and the University of Pittsburgh Alzheimer Disease Research Center [DeMichele-Sweet et al., 2011b]. All AD cases met criteria for either possible, probable or definite AD [McKhann et al., 1984; Mirra et al., 1991]. All elderly controls were screened for dementia using structured clinical assessments or were determined to be free from neurodegenerative disease at neuropathological examination. Following quality control (QC) there were 1,299 cases with $\mathrm{AD}+\mathrm{P}, 735$ with $\mathrm{AD}-\mathrm{P}$, and 5,659 controls. The AD+P versus AD-P analysis included 1,882,172 SNPs, AD+P versus control analyses 1,847,262 SNPs.

When comparing $\mathrm{AD}+\mathrm{P}$ to $\mathrm{AD}-\mathrm{P}$ cases, the $\mathrm{SNP}$ with the strongest evidence for association with psychosis was rs753129 which is located in an intergenic region of chromosome 4 (OR $\left.=0.66 ; P=2.85 \times 10^{-7}\right)$. SNP rs6834555 was found to be the most statistically significant $\mathrm{SNP}$ when comparing AD+P cases to controls (although it should be noted that no SNP reached the threshold of genome wide significance in this report). This SNP is upstream of the solute carrier family two member $9(S L C 2 A 9)$ gene ( $\left.\mathrm{OR}=1.39, P=3.0 \times 10^{-7}\right)$. However, when comparing $\mathrm{AD}+\mathrm{P}$ to $\mathrm{AD}-\mathrm{P}$ cases, the association of $\mathrm{AD}+\mathrm{P}$ with this $\mathrm{SNP}$ was no longer present [Hollingworth et al., 2012]. An intronic SNP, rs4038131, in the visinin-like 1 ( VSNL1) gene approached statistical significance in both $\mathrm{AD}+\mathrm{P}$ versus control $(\mathrm{OR}=0.65, P$ $\left.=5.9 \times 10^{-7}\right)$ and $\mathrm{AD}+\mathrm{P}$ versus $\mathrm{AD}-\mathrm{P}$ groups $\left(\mathrm{OR}=0.72, P=1.84 \times 10^{-2}\right)$ Hollingworth et al. [2012]. VSNL1 codes for the protein, VILIP-1, neuronal calcium sensor [Amici et al., 2009]. VILIP-1 has been shown to be a cerebrospinal fluid biomarker of Alzheimer disease [Lee et al., 2008; Tarawneh et al., 2011].

Additionally, this GWAS by Hollingworth et al. [2012] included an investigation on 11 SNPs that have shown genome-wide significance in GWAS of bipolar disorder and schizophrenia. Independently, none of the SNPs had a significant genome-wide association with $\mathrm{AD}+\mathrm{P}$, but as a group there was a trend towards association $\left(P_{\text {combined }}=0.109\right)$ [Hollingworth et al., 2012]. 


\section{Copy Number Variants}

Rare structural variation such as copy number variants (CNVs) are a growing area of interest in risk for neuropsychiatric disorders. CNVs are genomic regions that have added (duplications) or deleted (deletions) genetic material. They may overlap one or more genes, thereby affecting their function. Recent studies have shown that autism and schizophrenia share several rare CNVs [Carroll and Owen, 2009; Heinzen et al., 2010]. Genome-wide scans for CNVs have been conducted recently to identify genetic factors associated with AD [Heinzen et al., 2010; Shaw et al., 2011; Ghani et al., 2012; Rovelet-Lecrux et al., 2012; Swaminathan et al., 2012; Chapman et al., 2013; Guffanti et al., 2013; Szigeti et al., 2013, 2014]. More recently, some studies have evaluated CNVs in AD+P.

Zheng et al. [2014] evaluated whether seven CNVs that have demonstrated recurrence in autism and schizophrenia were present in $\mathrm{AD}+\mathrm{P}$. Of these, a large duplication on chromosome 16p11.2 was found to be present in two of $440 \mathrm{AD}+\mathrm{P}$ subjects (frequency of $0.46 \%$ ) but in none of $136 \mathrm{AD}-\mathrm{P}$ subjects, none of 593 subjects with $\mathrm{AD}$ +intermediate psychosis, and none of 855 non-AD controls $(P=0.047)$. This finding suggests that the $16 \mathrm{p} 11.2$ duplication may act to increase risk for neuropsychiatric illness across developmental epochs, being associated with autism, then schizophrenia, and finally AD+P [Weiss et al., 2008; McCarthy et al., 2009]. The CNV region involved contains about 25 genes, several of which have been found to be involved in the pathogenesis of AD (SPN, CORO1A, QPRT, MAZ, MAPK3). The CNV duplication seen in this study almost fully overlaps with the previously reported $16 \mathrm{p} 11.2 \mathrm{CNV}$ region in schizophrenia and autism. The frequency of this $\mathrm{CNV}$ duplication in $\mathrm{AD}+\mathrm{P}(0.46 \%)$ is comparable to that reported in the sample of a large schizophrenia study where 21 of $4551(0.46 \%)$ cases had the duplication [McCarthy et al., 2009]. However, given that only two participants with AD+P had the 16p11.2 duplication, replication with larger cohorts is needed to enhance confidence in the association of this locus with $\mathrm{AD}+\mathrm{P}$.

To more systematically identify the association of CNVs with AD+P, Zheng et al. [2015] conducted the first genome-wide CNV study of AD+P. They looked at $496 \mathrm{AD}+\mathrm{P}$ cases, 639 subjects with $\mathrm{AD}$ +intermediate psychosis and $156 \mathrm{AD}-\mathrm{P}$ subjects. CNV load analysis found no significant difference in total and average CNV length and CNV number in the AD $+\mathrm{P}$ or $\mathrm{AD}$ intermediate $\mathrm{P}$ groups compared with the $\mathrm{AD}-\mathrm{P}$ group. Their analysis revealed a marginally significant lower number of duplication events in $\mathrm{AD}+\mathrm{P}$ cases compared with AD-P controls $(P=0.059)$. An interesting discovery was the presence of a duplication in the $A P C 2$ gene on chromosome $19 \mathrm{p} 13.3$, which was protective against AD+P $(\mathrm{OR}=0.42 ; P$ $=7.2 \times 10^{-10}$ ). The frequency of this duplication was $9.8 \%$ in $\mathrm{AD}+\mathrm{P}$ compared with $24.3 \%$ in AD-P. This study also found four other duplications and two deletions that did not achieve genome-wide significance summarized in Table II.

\section{CONCLUSION}

In this review, we have attempted to summarize the current knowledge of $\mathrm{AD}+\mathrm{P}$ genetics covering older familial aggregation and association studies to newer GWAS and CNV studies. 
Familial aggregation and heritability studies have been crucial for establishing that psychosis risk within $\mathrm{AD}$ is likely to be influenced by genetic variation. Several independent replications have established the familial aggregation of $\mathrm{AD}+\mathrm{P}$, while two independent studies estimated the heritability of psychosis in AD at $61 \%$. This indicates a substantial genetic component, approaching both heritability estimates for AD itself and for the major primary psychotic disorder, schizophrenia.

Despite the evidence of the heritability of psychosis in $\mathrm{AD}$, genetic studies to date have not been definitive. Most early studies of the genetics of $\mathrm{AD}+\mathrm{P}$ used linkage analysis or tested candidate genes, approaches that have largely been abandoned in favor of genome-wide association in studies of polygenic disorders, as is presumed to be the case for $\mathrm{AD}+\mathrm{P}$. However, some possible exceptions should be noted. It remains possible that some of the familial risk for $\mathrm{AD}+\mathrm{P}$ could reflect rare mutations of large effect within select families, and thus could be detectable using linkage approaches, although preferably within pedigrees much larger than most studied to date. Similarly, a possible exception to the above conclusion as it relates to candidate gene studies has been the study of $A P O E$ in $\mathrm{AD}+\mathrm{P}$. There is substantial support to conclude that $A P O E$ is not associated with risk for $\mathrm{AD}+\mathrm{P}$.

Recently, a few studies have used genome wide approaches to evaluate SNPs and CNVs for association with $\mathrm{AD}+\mathrm{P}$. A limitation to these studies has been their relatively small sample sizes, and thus limited statistical power, to date. For example, although the single GWAS study of $\mathrm{AD}+\mathrm{P}$ provided a number of suggestive associations of common variants, no single variant reached the genome-wide significance threshold. While some CNV studies have been promising, for example finding a genome-wide significant association of $\mathrm{AD}+\mathrm{P}$ with a protective effect of a duplication of the $A P C 2$ gene, many studied CNVs have low frequencies. As a result, even a small shift in CNV rates between cases and controls can eliminate putative associations, and so larger samples with independent replications are needed before concluding that detected associations are true positives.

Thus clearly larger samples of $\mathrm{AD}+\mathrm{P}$ and $\mathrm{AD}-\mathrm{P}$ subjects are needed for definitive genomewide association methods. This is not a trivial task, and requires careful attention to longitudinal behavioral characterizations and phenotyping. Individuals with AD must be followed into the period of moderate impairments at which the greatest risk of psychosis occurs. Otherwise, characterizing individuals as AD-P before reaching this threshold will substantially reduce the ability to detect associations as many such "non-psychotic" subjects would have demonstrated psychosis had they been followed longer. Similarly, a large number of subjects with an intermediate phenotype, some of whom are phenocopies, but some of whom are true $\mathrm{AD}+\mathrm{P}$ cases, are present in most samples. Longer follow-up will similarly benefit clarifying these intermediate phenotypes. However, at a practical level, many such cases will be present in any potential study sample. It would therefore be desirable to increase sample sizes and statistical power by developing methods that would provide appropriate weighting of these individuals (based on similar individuals for whom complete longitudinal data is available) for inclusion in association studies. 


\section{References}

Amici M, Doherty A, Jo J, Jane D, Cho K, Collingridge G, Dargan S. Neuronal calcium sensors and synaptic plasticity. Biochem Soc Trans. 2009; 37:1359-1363. [PubMed: 19909276]

Assal F, Alarcón M, Solomon EC, Masterman D, Geschwind DH, Cummings JL. Association of the serotonin transporter and receptor gene polymorphisms in neuropsychiatric symptoms in Alzheimer disease. Arch Neurol. 2004; 61:1249-1253. [PubMed: 15313842]

Avramopoulos D, Fallin MD, Bassett SS. Linkage to chromosome 14q in Alzheimer's disease (AD) patients without psychotic symptoms. Am J Med Genet B Neuropsychiatr Genet. 2005; 132B:9-13. [PubMed: 15389761]

Bacanu SA, Devlin B, Chowdari KV, DeKosky ST, Nimgaonkar VL, Sweet RA. Linkage analysis of Alzheimer disease with psychosis. Neurology. 2002; 59:118-120. [PubMed: 12105318]

Bacanu SA, Devlin B, Chowdari K, DeKosky S, Nimgaonkar V, Sweet RA. Heritability of psychosis in Alzheimer disease. Am J Geriatr Psychiatry. 2005; 13:624-627. [PubMed: 16009739]

Barral S, Vardarajan B, Faber KM, Bird TD, Tsuang D, Bennett DA, Rosenberg R, Boeve BF, GraffRadford NR, Goate AM, Farlow M, Lantigua R, Medrano MZ, Wang X, Kamboh MI, Barmada MM, Schaid DJ, Foroud TM, Weamer EA, Ottman R, Sweet RA, Mayeux R. Genetic variants associated with susceptibility to psychosis in late onset Alzheimer disease families. Neurobiol Aging. 2015; doi: 10.1016/j.neurobiolaging.2015.08.006

Bertram L, Tanzi RE. The genetic epidemiology of neurodegenerative disease. J Clin Invest. 2005; 115:1449-1457. [PubMed: 15931380]

Borroni B, Grassi M, Agosti C, Costanzi C, Archetti S, Franzoni S, Caltagirone C, Di LM, Caimi L, Padovani A. Genetic correlates of behavioral endophenotypes in Alzheimer disease: Role of COMT, 5-HTTLPR, and APOE polymorphisms. Neurobiol Aging. 2006; 27:1595-1603. [PubMed: 16257094]

Borroni B, Grassi M, Costanzi C, Zanetti M, Archetti S, Franzoni S, Caimi L, Padovani A. Haplotypes in cathechol-O-methyltransferase gene confer increased risk for psychosis in Alzheimer disease. Neurobiol Aging. 2007; 28:1231-1238. [PubMed: 16837108]

Burns A, Jacoby R, Levy R. Psychiatric phenomena in Alzheimer's disease. I: Disorders of thought content. Br J Psychiatry. 1990; 157:72-76. 92-94. [PubMed: 2397365]

Campion D, Dumanchin C, Hannequin D, Dubois B, Belliard S, Puel M, Thomas-Anterion C, Michon A, Martin C, Charbonnier F, Raux G, Camuzat A, Penet C, Mesnage V, Martinez M, ClergetDarpoux F, Brice A, Frebourg T. Early-onset autosomal dominant Alzheimer disease: Prevalence, genetic heterogeneity, and mutation spectrum. Am J Hum Genet. 1999; 65:664-670. [PubMed: 10441572]

Carroll LS, Owen MJ. Genetic overlap between autism, schizophrenia and bipolar disorder. Genome Med. 2009; 1:102. [PubMed: 19886976]

Chapman J, Rees E, Harold D, Ivanov D, Gerrish A, Sims R, Hollingworth P, Stretton A, Holmans P, Owen MJ, O’Donovan MC, Williams J, Kirov G. A genome-wide study shows a limited contribution of rare copy number variants to Alzheimer's disease risk. Hum Mol Genet. 2013; 22:816-824. [PubMed: 23148125]

Chouraki V, Seshadri S. Genetics of Alzheimer's disease. Adv Genet. 2014; 87:245-294. [PubMed: 25311924]

Christie D, Shofer J, Millard SP, Li E, DeMichele-Sweet MA, Weamer EA, Kamboh MI, Lopez OL, Sweet RA, Tsuang D. Genetic association between APOE* 4 and neuropsychiatric symptoms in patients with probable Alzheimer's disease is dependent on the psychosis phenotype. Behav Brain Funct. 2012; 8:62. [PubMed: 23270420]

Chu SH, Roeder K, Ferrell RE, Devlin B, DeMichele-Sweet MA, Kamboh M, Lopez OL, Sweet RA. TOMM40 poly-T repeat lengths, age of onset and psychosis risk in Alzheimer disease. Neurobiol Aging. 2011; 32:2328e1-e9. [PubMed: 21820212]

Corder EH, Saunders AM, Strittmatter WJ, Schmechel DE, Gaskell PC, Small GW, Roses AD, Haines JL, Pericak-Vance MA. Gene dose of apolipoprotein E type 4 allele and the risk of Alzheimer's disease in late onset families. Science. 1993; 261:921-923. [PubMed: 8346443] 
Craig D, Hart DJ, Carson R, McIlroy SP, Passmore AP. Psychotic symptoms in Alzheimer's disease are not influenced by polymorphic variation at the dopamine receptor DRD3 gene. Neurosci Lett. 2004; 368:33-36. [PubMed: 15342129]

Craig D, Donnelly C, Hart D, Carson R, Passmore P. Analysis of the 5HT-2A T102C receptor polymorphism and psychotic symptoms in Alzheimer's disease. Am J Med Genet B Neuropsychiatr Genet. 2007; 144B:126-128. [PubMed: 16967466]

DeMichele-Sweet MA, Sweet RA. Genetics of psychosis in Alzheimer's disease: A review. J Alzheimers Dis. 2010; 19:761-780. [PubMed: 20157235]

DeMichele-Sweet MA, Klein L, Devlin B, Ferrell RE, Weamer EA, Emanuel JE, Lopez OL, Sweet RA. No association of psychosis in Alzheimer disease with neurodegenerative pathway genes. Neurobiol Aging. 2011b; 32:555e9-e11.

DeMichele-Sweet MA, Lopez OL, Sweet RA. Psychosisin Alzheimer's disease in the national Alzheimer's disease coordinating center uniform data set: Clinical correlates and association with apolipoprotein e. Int J Alzheimers Dis. 2011a:926597. [PubMed: 21461363]

Devanand DP, Miller L, Richards M, Marder K, Bell K, Mayeux R, Stern Y. The Columbia university scale for psychopathology in Alzheimer's disease. Arch Neurol. 1992; 49:371-376. [PubMed: 1558517]

DiMaria E, Bonvicini C, Bonomini C, Alberici A, Zanetti O, Gennarelli M. Genetic variation in the G720/G30 gene locus (DAOA) influences the occurrence of psychotic symptoms in patients with Alzheimer's disease. J Alzheimers Dis. 2009; 18:953-960. [PubMed: 20009237]

Ghani M, Pinto D, Lee JH, Grinberg Y, Sato C, Moreno D, Scherer SW, Mayeux R, St George-Hyslop $\mathrm{P}$, Rogaeva E. Genome-wide survey of large rare copy number variants in Alzheimer's disease among Caribbean hispanics. G3 (Bethesda). 2012; 2:71-78. [PubMed: 22384383]

Gilley DW, Whalen ME, Wilson RS, Bennett DA. Hallucinations and associated factors in Alzheimer's disease. J Neuropsychiatry Clin Neurosci. 1991; 3:371-376. [PubMed: 1821255]

Gilley DW, Wilson RS, Beckett LA, Evans DA. Psychotic symptoms and physically aggressive behavior in Alzheimer's disease. J Am Geriatr Soc. 1997; 45:1074-1079. [PubMed: 9288014]

Go RC, Perry RT, Wiener H, Bassett SS, Blacker D, Devlin B, Sweet RA. Neuregulin-1 polymorphism in late onset Alzheimer's disease families with psychoses. Am J Med Genet B Neuropsychiatr Genet. 2005; 139B:28-32. [PubMed: 16082692]

Goate A, Chartier-Harlin MC, Mullan M, Brown J, Crawford F, Fidani L, Giuffra L, Haynes A, Irving $\mathrm{N}$, James L. Segregation of a missense mutation in the amyloid precursor protein gene with familial Alzheimer's disease. Nature. 1991; 349:704-706. [PubMed: 1671712]

Guffanti G, Torri F, Rasmussen J, Clark AP, Lakatos A, Turner JA, Fallon JH, Saykin AJ, Weiner M, Vawter MP, Knowles JA, Potkin SG, Macciardi F. Increased CNV-region deletions in mild cognitive impairment (MCI) and Alzheimer's disease (AD) subjects in the ADNI sample. Genomics. 2013; 102:112-122. [PubMed: 23583670]

Ha TM, Cho DM, Park SW, Joo MJ, Lee BJ, Kong BG, Kim JM, Yoon JS, Kim YH. Evaluating associations between 5-HTTLPR polymorphism and Alzheimer's disease for Korean patients. Dement Geriatr Cogn Disord. 2005; 20:31-34. [PubMed: 15832033]

Harold D, Abraham R, Hollingworth P, Sims R, Gerrish A, Hamshere ML, Pahwa JS, Moskvina V, Dowzell K, Williams A, Jones N, Thomas C, Stretton A, Morgan AR, Lovestone S, Powell J, Proitsi P, Lupton MK, Brayne C, Rubinsztein DC, Gill M, Lawlor B, Lynch A, Morgan K, Brown KS, Passmore PA, Craig D, McGuinness B, Todd S, Holmes C, Mann D, Smith AD, Love S, Kehoe PG, Hardy J, Mead S, Fox N, Rossor M, Collinge J, Maier W, Jessen F, Schürmann B, Heun R, vanden BH, Heuser I, Kornhuber J, Wiltfang J, Dichgans M, Frölich L, Hampel H, Hüll M, Rujescu D, Goate AM, Kauwe JS, Cruchaga C, Nowotny P, Morris JC, Mayo K, Sleegers K, Bettens K, Engelborghs S, DeDeyn PP, VanBroeckhoven C, Livingston G, Bass NJ, Gurling H, McQuillin A, Gwilliam R, Deloukas P, Al-Chalabi A, Shaw CE, Tsolaki M, Singleton AB, Guerreiro R, Mühleisen TW, Nöthen MM, Moebus S, Jöckel KH, Klopp N, Wichmann HE, Carrasquillo MM, Pankratz VS, Younkin SG, Holmans PA, O’Donovan M, Owen MJ, Williams J. Genome-wide association study identifies variants at CLU and PICALM associated with Alzheimer's disease. Nat Genet. 2009; 41:1088-1093. [PubMed: 19734902]

Harrison PJ, Law AJ. Neuregulin 1 and schizophrenia: Genetics, gene expression, and neurobiology. Biol Psychiatry. 2006; 60:132-140. [PubMed: 16442083] 
Heinzen EL, Need AC, Hayden KM, Chiba-Falek O, Roses AD, Strittmatter WJ, Burke JR, Hulette CM, Welsh-Bohmer KA, Goldstein DB. Genome-wide scan of copy number variation in late-onset Alzheimer's disease. J Alzheimers Dis. 2010; 19:69-77. [PubMed: 20061627]

Hollingworth P, Hamshere ML, Holmans PA, O’Donovan MC, Sims R, Powell J, Lovestone S, Myers A, DeVrieze FW, Hardy J, Goate J, Owen M, Williams J. Increased familial risk and genomewide significant linkage for Alzheimer's disease with psychosis. Am J Med Genet B Neuropsychiatr Genet. 2007; 144B:841-848. [PubMed: 17492769]

Hollingworth P, Sweet R, Sims R, Harold D, Russo G, Abraham R, Stretton A, Jones N, Gerrish A, Chapman J, Ivanov D, Moskvina V, Lovestone S, Priotsi P, Lupton M, Brayne C, Gill M, Lawlor B, Lynch A, Craig D, McGuinness B, Johnston J, Holmes C, Livingston G, Bass NJ, Gurling H, McQuillin A, Holmans P, Jones L, Devlin B, Klei L, Barmada MM, Demirci FY, DeKosky ST, Lopez OL, Passmore P, Owen MJ, O’Donovan MC, Mayeux R, Kamboh MI, Williams J. GERAD Consortium; National Institute on Aging Late-Onset Alzheimer's Disease Family Study Group. Genome-wide association study of Alzheimer's disease with psychotic symptoms. Mol Psychiatry. 2012; 17:1316-1327. [PubMed: 22005930]

Holmes C, Arranz MJ, Powell JF, Collier DA, Lovestone S. 5-HT2A and 5-HT2C receptor polymorphisms and psychopathology in late onset Alzheimer's disease. Hum Mol Genet. 1998; 7:1507-1509. [PubMed: 9700207]

Holmes C, Smith H, Ganderton R, Arranz M, Collier D, Powell J, Lovestone S. Psychosis and aggression in Alzheimer's disease: The effect of dopamine receptor gene variation. J Neurol Neurosurg Psychiatry. 2001; 71:777-779. [PubMed: 11723200]

Huybrechts KF, Gerhard T, Crystal S, Olfson M, Avorn J, Levin R, Lucas JA, Schneeweiss S. Differential risk of death in older residents in nursing homes prescribed specific antipsychotic drugs: Population based cohort study. BMJ. 2012; 344:e977. [PubMed: 22362541]

Jeste DV, Finkel SI. Psychosis of Alzheimer's disease and related dementias. Diagnostic criteria for a distinct syndrome. Am J Geriatr Psychiatry. 2000; 8:29-34. [PubMed: 10648292]

Kaufer DI, Cummings JL, Christine D, Bray T, Castellon S, Masterman D, MacMillan A, Ketchel P, DeKosky ST. Assessing the impact of neuropsychiatric symptoms in Alzheimer's disease: The neuropsychiatric inventory caregiver distress scale. J Am Geriatr Soc. 1998; 46:210-215. [PubMed: 9475452]

Lam LC, Tang NL, Ma SL, Zhang W, Chiu HF. 5-HT2A T102C receptor polymorphism and neuropsychiatric symptoms in Alzheimer's disease. Int J Geriatr Psychiatry. 2004; 19:523-526. [PubMed: 15211529]

Lee JM, Blennow K, Andreasen N, Laterza O, Modur V, Olander J, Gao F, Ohlendorf M, Ladenson $\mathrm{JH}$. The brain injury biomarker VLP-1 is increased in the cerebrospinal fluid of Alzheimer disease patients. Clin Chem. 2008; 54:1617-1623. [PubMed: 18703769]

Levy-Lahad E, Wasco W, Poorkaj P, Romano DM, Oshima J, Pettingell WH, Yu CE, Jondro PD, Schmidt SD, Wang K. Candidate gene for the chromosome 1 familial Alzheimer's disease locus. Science. 1995; 269:973-977. [PubMed: 7638622]

Lyketsos CG, Sheppard JM, Steinberg M, Tschanz JA, Norton MC, Steffens DC, Breitner JC. Neuropsychiatric disturbance in Alzheimer's disease clusters into three groups: The cache county study. Int J Geriatr Psychiatry. 2001; 16:1043-1053. [PubMed: 11746650]

McCarthy SE, Makarov V, Kirov G, Addington AM, McClellan J, Yoon S, Perkins DO, Dickel DE, Kusenda M, Krastoshevsky O, Krause V, Kumar RA, Grozeva D, Malhotra D, Walsh T, Zackai EH, Kaplan P, Ganesh J, Krantz ID, Spinner NB, Roccanova P, Bhandari A, Pavon K, Lakshmi B, Leotta A, Kendall J, Lee YH, Vacic V, Gary S, Iakoucheva LM, Crow TJ, Christian SL, Lieberman JA, Stroup TS, Lehtimäki T, Puura K, Haldeman-Englert C, Pearl J, Goodell M, Willour VL, Derosse P, Steele J, Kassem L, Wolff J, Chitkara N, McMahon FJ, Malhotra AK, Potash JB, Schulze TG, Nöthen MM, Cichon S, Rietschel M, Leibenluft E, Kustanovich V, Lajonchere CM, Sutcliffe JS, Skuse D, Gill M, Gallagher L, Mendell NR, Craddock N, Owen MJ, O'Donovan MC, Shaikh TH, Susser E, Delisi LE, Sullivan PF, Deutsch CK, Rapoport J, Levy DL, King MC, Sebat J. Microduplications of 16p11.2 are associated with schizophrenia. Nat Genet. 2009; 41:12231227. [PubMed: 19855392]

McKhann G, Drachman D, Folstein M, Katzman R, Price D, Stadlan EM. Clinical diagnosis of Alzheimer's disease: Report of the NINCDS-ADRDA work group under the auspices of 
department of health and human services task force on Alzheimer's disease. Neurology. 1984; 34:939-944. [PubMed: 6610841]

Mirra SS, Heyman A, McKeel D, Sumi SM, Crain BJ, Brownlee LM, Vogel FS, Hughes JP, vanBelle G, Berg L. The consortium to establish a registry for Alzheimer's disease (CERAD). Part II. Standardization of the neuropathologic assessment of Alzheimer's disease. Neurology. 1991; 41:479-486. [PubMed: 2011243]

Murray PS, Kumar K, DeMichele-Sweet MA, Sweet RA. Psychosis in Alzheimer's disease. Biol Psychiatry. 2014; 75:542-552. [PubMed: 24103379]

Nacmias B, Tedde A, Forleo P, Piacentini S, Guarnieri BM, Bartoli A, Ortenzi L, Petruzzi C, Serio A, Marcon G, Sorbi S. Association between 5-HT(2A) receptor polymorphism and psychotic symptoms in Alzheimer's disease. Biol Psychiatry. 2001; 50:472-475. [PubMed: 11566166]

Pritchard AL, Pritchard CW, Bentham P, Lendon CL. Role of serotonin transporter polymorphisms in the behavioural and psychological symptoms in probable Alzheimer disease patients. Dement Geriatr Cogn Disord. 2007; 24:201-206. [PubMed: 17690552]

Pritchard AL, Harris J, Pritchard CW, Coates J, Haque S, Holder R, Bentham P, Lendon CL. Role of 5HT 2A and 5HT 2C polymorphisms in behavioural and psychological symptoms of Alzheimer's disease. Neurobiol Aging. 2008a; 29:341-347. [PubMed: 17098333]

Pritchard AL, Pritchard CW, Bentham P, Lendon CL. Investigation of the role of the dopamine transporter in susceptibility to behavioural and psychological symptoms of patients with probable Alzheimer's disease. Dement Geriatr Cogn Disord. 2008b; 26:257-260. [PubMed: 18841010]

Rocchi A, Micheli D, Ceravolo R, Manca ML, Tognoni G, Siciliano G, Murri L. Serotoninergic polymorphisms (5-HTTLPR and 5-HT2A): Association studies with psychosis in Alzheimer disease. Genet Test. 2003; 7:309-314. [PubMed: 15000807]

Ropacki SA, Jeste DV. Epidemiology of and risk factors for psychosis of Alzheimer's disease: A review of 55 studies published from 1990 to 2003. Am J Psychiatry. 2005; 162:2022-2030. [PubMed: 16263838]

Roses AD, Lutz MW, Amrine-Madsen H, Saunders AM, Crenshaw DG, Sundseth SS, Huentelman MJ, Welsh-Bohmer KA, Reiman EM. A TOMM40 variable-length polymorphism predicts the age of late-onset Alzheimer's disease. Pharmacogenomics J. 2010; 10:375-384. [PubMed: 20029386]

Rovelet-Lecrux A, Hannequin D, Raux G, LeMeur N, Laquerrière A, Vital A, Dumanchin C, Feuillette S, Brice A, Vercelletto M, Dubas F, Frebourg T, Campion D. APP locus duplication causes autosomal dominant early-onset Alzheimer disease with cerebral amyloid angiopathy. Nat Genet. 2006; 38:24-26. [PubMed: 16369530]

Rovelet-Lecrux A, Legallic S, Wallon D, Flaman JM, Martinaud O, Bombois S, Rollin-Sillaire A, Michon A, Le Ber I, Pariente J, Puel M, Paquet C, Croisile B, Thomas-Antérion C, Vercelletto M, Lévy R, Frébourg T, Hannequin D, Campion D. Investigators of the GMAJ Project. A genomewide study reveals rare CNVs exclusive to extreme phenotypes of Alzheimer disease. Eur J Hum Genet. 2012; 20:613-617. [PubMed: 22166940]

Scarmeas N, Brandt J, Albert M, Hadjigeorgiou G, Papadimitriou A, Dubois B, Sarazin M, Devanand D, Honig L, Marder K, Bell K, Wegesin D, Blacker D, Stern Y. Delusions and hallucinations are associated with worse outcome in Alzheimer disease. Arch Neurol. 2005; 62:1601-1608. [PubMed: 16216946]

Schizophrenia Working Group of the Psychiatric Genomics Consortium. Biological insights from 108 schizophrenia-associated genetic loci. Nature. 2014; 511:421-427. [PubMed: 25056061]

Schneider LS, Dagerman K, Insel PS. Efficacy and adverse effects of atypical antipsychotics for dementia: Meta-analysis of randomized, placebo-controlled trials. Am J Geriatr Psychiatry. 2006; 14:191-210. [PubMed: 16505124]

Shaw CA, Li Y, Wiszniewska J, Chasse S, Zaidi SN, Jin W, Dawson B, Wilhelmsen K, Lupski JR, Belmont JW, Doody RS, Szigeti K. Olfactory copy number association with age at onset of Alzheimer disease. Neurology. 2011; 76:1302-1309. [PubMed: 21482944]

Sherrington R, Rogaev EI, Liang Y, Rogaeva EA, Levesque G, Ikeda M, Chi H, Lin C, Li G, Holman K, Tsuda T, Mar L, Foncin JF, Bruni AC, Montesi MP, Sorbi S, Rainero I, Pinessi L, Nee L, Chumakov I, Pollen D, Brookes A, Sanseau P, Polinsky RJ, Wasco W, DaSilva HA, Haines JL, Perkicak-Vance MA, Tanz RE, Roses AD, Fraser PE, Rommens JM, St George-Hyslop PH. 
Cloning of a gene bearing missense mutations in early-onset familial Alzheimer's disease. Nature. 1995; 375:754-760. [PubMed: 7596406]

Stefansson H, Sigurdsson E, Steinthorsdottir V, Bjornsdottir S, Sigmundsson T, Ghosh S, Brynjolfsson J, Gunnarsdottir S, Ivarsson O, Chou TT, Hjaltason O, Birgisdottir B, Jonsson H, Gudnadottir VG, Gudmundsdottir E, Bjornsson A, Ingvarsson B, Ingason A, Sigfusson S, Hardardottir H, Harvey RP, Lai P, Zhou M, Brunner D, Mutel V, Gonzalo A, Lemke G, Sainz J, Johannesson G, Andresson T, Gudbjartsson D, Manolescu A, Frigge ML, Gurney ME, Kong A, Gulcher JR, Petursson H, Stefansson K. Neuregulin 1 and susceptibility to schizophrenia. Am J Hum Genet. 2002; 71:877892. [PubMed: 12145742]

Steinberg S, Mors O, Børglum AD, Gustafsson O, Werge T, Mortensen PB, Andreassen OA, Sigurdsson E, Thorgeirsson TE, Böttcher Y, Olason P, Ophoff RA, Cichon S, Gudjonsdottir IH, Pietiläinen OP, Nyegaard M, Tuulio-Henriksson A, Ingason A, Hansen T, Athanasiu L, Suvisaari J, Lonnqvist J, Paunio T, Hartmann A, Jürgens G, Nordentoft M, Hougaard D, Norgaard-Pedersen B, Breuer R, Möller HJ, Giegling I, Glenthøj B, Rasmussen HB, Mattheisen M, Bitter I, Réthelyi JM, Sigmundsson T, Fossdal R, Thorsteinsdottir U, Ruggeri M, Tosato S, Strengman E, Kiemeney LA, Melle I, Djurovic S, Abramova L, Kaleda V, Walshe M, Bramon E, Vassos E, Li T, Fraser G, Walker N, Toulopoulou T, Yoon J, Freimer NB, Cantor RM, Murray R, Kong A, Golimbet V, Jönsson EG, Terenius L, Agartz I, Petursson H, Nöthen MM, Rietschel M, Peltonen L, Rujescu D, Collier DA, Stefansson H, St Clair D, Stefansson K. Genetic Risk and Outcome in Psychosis. Expanding the range of ZNF804A variants conferring risk of psychosis. Mol Psychiatry. 2011; 16:59-66. [PubMed: 20048749]

Strittmatter WJ, Saunders AM, Schmechel D, Pericak-Vance M, Enghild J, Salvesen GS, Roses AD. Apolipoprotein E: High-avidity binding to beta-amyloid and increased frequency of type 4 allele in late-onset familial Alzheimer disease. Proc Natl Acad Sci USA. 1993; 90:1977-1981. [PubMed: 8446617]

Swaminathan S, Shen L, Kim S, Inlow M, West JD, Faber KM, Foroud T, Mayeux R, Saykin AJ. Analysis of copy number variation in Alzheimer's disease: The NIALOAD/NCRAD family study. Curr Alzheimer Res. 2012; 9:801-814. [PubMed: 22486522]

Sweet RA, Nimgaonkar VL, Kamboh MI, Lopez OL, Zhang F, DeKosky ST. Dopamine receptor genetic variation, psychosis, and aggression in Alzheimer disease. Arch Neurol. 1998; 55:13351340. [PubMed: 9779662]

Sweet RA, Pollock BG, Sukonick DL, Mulsant BH, Rosen J, Klunk WE, Kastango KB, DeKosky ST, Ferrell RE. The 5-HTTPR polymorphism confers liability to a combined phenotype of psychotic and aggressive behavior in Alzheimer disease. Int Psychogeriatr. 2001; 13:401-409. [PubMed: 12003247]

Sweet RA, Nimgaonkar VL, Devlin B, Lopez OL, DeKosky ST. Increased familial risk of the psychotic phenotype of Alzheimer disease. Neurology. 2002; 58:907-911. [PubMed: 11914406]

Sweet RA, Devlin B, Pollock BG, Sukonick DL, Kastango KB, Bacanu SA, Chowdari K, DeKosky ST, Ferrell RE. Catechol-O-methyltransferase haplotypes are associated with psychosis in Alzheimer disease. Mol Psychiatry. 2005; 10:1026-1036. [PubMed: 16027741]

Sweet RA, Bennett DA, Graff-Radford NR, Mayeux R. Assessment and familial aggregation of psychosis in Alzheimer's disease from the national institute on aging late onset Alzheimer's disease family study. Brain. 2010; 133:1155-1162. [PubMed: 20147454]

Szigeti K, Lal D, Li Y, Doody RS, Wilhelmsen K, Yan L, Liu S, Ma C. Genome-wide scan for copy number variation association with age at onset of Alzheimer's disease. J Alzheimers Dis. 2013; 33:517-523. [PubMed: 23202439]

Szigeti K, Kellermayer B, Lentini JM, Trummer B, Lal D, Doody RS, Yan L, Liu S, Ma C. Ordered subset analysis of copy number variation association with age at onset of Alzheimer's disease. J Alzheimers Dis. 2014; 41:1063-1071. [PubMed: 24787912]

Tarawneh R, D’Angelo G, Macy E, Xiong C, Carter D, Cairns NJ, Fagan AM, Head D, Mintun MA, Ladenson JH, Lee JM, Morris JC, Holtzman DM. Visinin-like protein-1: Diagnostic and prognostic biomarker in Alzheimer disease. Ann Neurol. 2011; 70:274-285. [PubMed: 21823155]

Tariot PN, Mack JL, Patterson MB, Edland SD, Weiner MF, Fillenbaum G, Blazina L, Teri L, Rubin E, Mortimer JA. The behavior rating scale for dementia of the consortium to establish a registry for 
Alzheimer's disease. The behavioral pathology committee of the consortium to establish a registry for Alzheimer's disease. Am J Psychiatry. 1995; 152:1349-1357. [PubMed: 7653692]

Tunstall N, Owen MJ, Williams J, Rice F, Carty S, Lillystone S, Fraser L, Kehoe P, Neill D, Rudrasingham V, Sham P, Lovestone S. Familial influence on variation in age of onset and behavioural phenotype in Alzheimer's disease. Br J Psychiatry. 2000; 176:156-159. [PubMed: 10755053]

Ueki A, Ueno H, Sato N, Shinjo H, Morita Y. Serotonin transporter gene polymorphism and BPSD in mild Alzheimer's disease. J Alzheimers Dis. 2007; 12:245-253. [PubMed: 18057558]

Weiss LA, Shen Y, Korn JM, Arking DE, Miller DT, Fossdal R, Saemundsen E, Stefansson H, Ferreira MA, Green T, Platt OS, Ruderfer DM, Walsh CA, Altshuler D, Chakravarti A, Tanzi RE, Stefansson K, Santangelo SL, Gusella JF, Sklar P, Wu BL, Daly MJ. Association between microdeletion and microduplication at 16p11.2 and autism. N Engl J Med. 2008; 358:667-675. [PubMed: 18184952]

Wijsman EM, Pankratz ND, Choi Y, Rothstein JH, Faber KM, Cheng R, Lee JH, Bird TD, Bennett DA, Diaz-Arrastia R, Goate AM, Farlow M, Ghetti B, Sweet RA, Foroud TM, Mayeux R. Genome-wide association of familial late-onset Alzheimer's disease replicates BIN1 and CLU and nominates CUGBP2 in interaction with APOE. PLoS Genet. 2011; 7:e1001308. [PubMed: 21379329]

Wilkosz PA, Kodavali C, Weamer EA, Miyahara S, Lopez OL, Nimgaonkar VL, DeKosky ST, Sweet RA. Prediction of psychosis onset in Alzheimer disease: the role of depression symptom severity and the HTR2A T102C polymorphism. Am J Med Genet B Neuropsychiatr Genet. 2007; 144B: 1054-1062. [PubMed: 17525976]

Wilson RS, Tang Y, Aggarwal NT, Gilley DW, McCann JJ, Bienias JL, Evans DA. Hallucinations, cognitive decline, and death in Alzheimer's disease. Neuroepidemiology. 2006; 26:68-75. [PubMed: 16352909]

Xu B, Roos JL, Levy S, vanRensburg EJ, Gogos JA, Karayiorgou M. Strong association of de novo copy number mutations with sporadic schizophrenia. Nat Genet. 2008; 40:880-885. [PubMed: 18511947]

Zheng X, Demirci FY, Barmada MM, Richardson GA, Lopez OL, Sweet RA, Kamboh MI, Feingold E. A rare duplication on chromosome 16p11.2 is identified in patients with psychosis in Alzheimer's disease. PLoS ONE. 2014; 9:e111462. [PubMed: 25379732]

Zheng X, Demirci FY, Barmada MM, Richardson GA, Lopez OL, Sweet RA, Kamboh MI, Feingold E. Genome-wide copy-number variation study of psychosis in Alzheimer's disease. Transl Psychiatry. 2015; 5:e574. [PubMed: 26035058] 


\section{TABLE I}

Studies With Significant Associations of AD+P to Serotonin and Dopamine Receptors, COMT, DAOA, APP, SORL1, BACE1, and MAPT

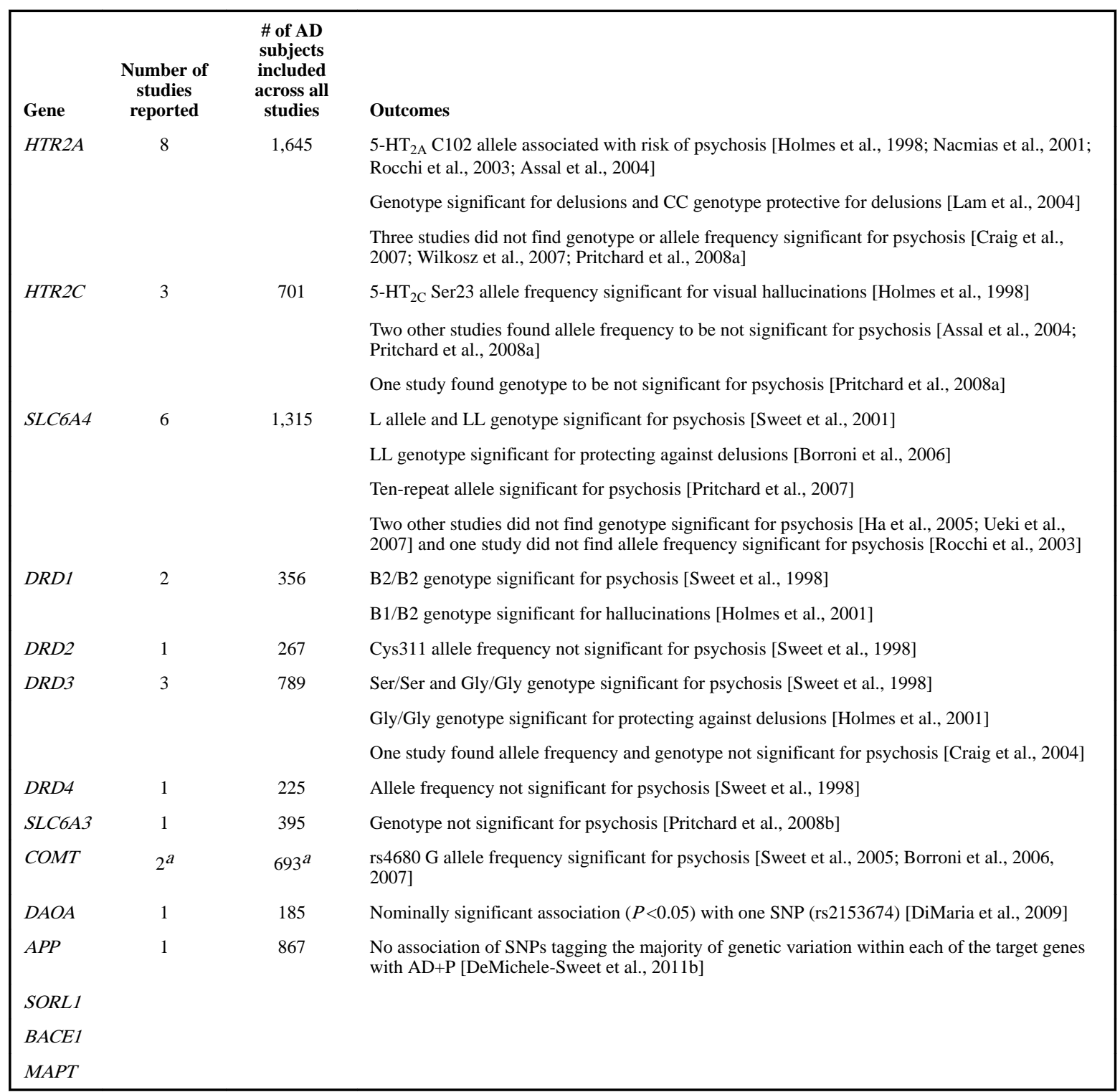

HTR2A, serotonin 2A receptor; HTR2C, serotonin 2C receptor; SLC6A4, serotonin transporter; DRD1, dopamine-1 receptor; DRD2, dopamine-2 receptor; $D R D 3$, dopamine-3 receptor; $D R D 4$, dopamine-4 receptor; $S L C 6 A 3$, dopamine transporter; $C O M T$, catechol-O-methyltransferase; $D A O A$, D-amino acid oxidase activator; $M A P T$, microtubule-associated protein tau; $A P P$, amyloid beta (A4) precursor protein; $B A C E 1$, beta-site APP-cleaving enzyme 1; SORL1, sortilin-related receptor, L(DLR Class) A repeats containing.

a Borroni et al. [2006] study had 232 subjects and the same study was continued with new results published in 2007 which included 88 new subjects with AD. 


\section{TABLE II}

CNVs Identified by Zheng et al. [2014, 2015]

\begin{tabular}{|lclcl|}
\hline Chromosome & CNV type & CNV position & Gene & Frequency in AD+P/AD int P/AD-P (\%); $P$-value \\
9 & Duplication & $130459243-130492493$ & $S E T$ & $6.1 / 16 / 17.6 ; 1.95 \times 10^{-6}$ \\
14 & & $104694657-104708792$ & $J A G 2$ & $4.8 / 17.7 / 14 ; 5.01 \times 10^{-7}$ \\
16 & & $87124205-87132458$ & $Z F P M 1$ & $7 / 21.4 / 18.4 ; 2.13 \times 10^{-7}$ \\
16 & & $29554843-30105652$ & 25 Different genes & $0.45 / 0 / 0 ; 0.047$ \\
17 & & No known gene & $7.5 / 21.8 / 14.7 ; 4.25 \times 10^{-6}$ \\
19 & & $1411473-1424152$ & APC2 & $9.8 / 29 / 24.3 ; 7.20 \times 10^{-10}$ \\
4 & Deletion & $162098516-162104179$ & No known gene & $26.1 / 19.6 / 12.5 ; 8.27 \times 10^{-5}$ \\
9 & & $17259437-17388404$ & $C N T L N$ & $1.6 / 0 / 0 ; 8.87 \times 10^{-4}$ \\
\hline
\end{tabular}

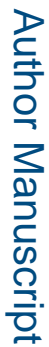

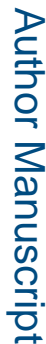

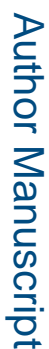

Am J Med Genet B Neuropsychiatr Genet. Author manuscript; available in PMC 2017 January 01. 